\title{
Investigation of foliar application of nano- micronutrient fertilizers and nano-titanium dioxide on some traits of barley
}

Mohsen Janmohammadi,

Naser Sabaghnia*,

Shahryar Dashti,

Mojtaba Nouraein

Department of Agronomy

and Plant Breeding,

Agriculture College,

University of Maragheh, Iran
Nanofertilizers are new products which contain readily available nutrients in the nanoscale range and are preferred largely due to their efficiency. To investigate the effects of micronutrient nanofertilizers (iron and zinc) as $\mathrm{F}$ factor and nano-titanium dioxide (nano- $\mathrm{TiO}_{2}$ ) solution as $\mathrm{n}$ factor on yield performance and some morphologic traits of barley, a field experiment was carried out with treating with chelated nanoscale zinc oxide (nano- $\mathrm{ZnO}$ ) and ferric oxide (nano- $\mathrm{Fe}_{2} \mathrm{O}_{3}$ ) suspensions during three phonological stages. The treatment combination by trait (TT) biplot was used for two-way dataset as various treatment combinations (Fn) with multiple traits. The GT biplot explained $83 \%$ of the total variation of the standardized data. The polygon view of TT showed five vertex treatment combinations as F1n1, F1n2, F2n2, F3n1, and F3n2. Therefore, it seems that F3n1 treatment combination had the highest values for all of the days to maturity, grain yield, straw yield, harvest index, spike length, number of fertile tillers, and grain weight per plant traits. The most prominent relations of tester-view biplot were: a strong positive association between days to maturity and straw yield and among grain yield, harvest index and spike length, while there was a near zero correlation of the number of tillers per plants with days to maturity and straw yield. It can be concluded that $\mathrm{TiO}_{2}$ nanoparticles and nano-micronutrient fertilizers (iron nano-chelate and zinc nano-chelate) could increase yield and yield components of barley. Our findings suggest that the foliar application of nanoparticles resulted in sustainable and high crop production, and among six treatment combinations, F3n2 (zinc nano-chelate with $2000 \mathrm{ppm}$ nano- $\mathrm{TiO}_{2}$ ) indicated the best performance for most of the measured traits of barley.

Key words: nanofertilizer, iron nano-chelate, $\mathrm{TiO}_{2}$ nanoparticle, zinc nano-chelate

\section{INTRODUCTION}

A balanced fertilization with macro- and micronutrients in crop nutrition is very imperative in good

*Correspondence: E-mail: sabaghnia@maragheh.ac.ir yield production. Of the micronutrients, iron is essential for crop growth and food production and is involved in the production of chlorophyll, photosynthesis, mitochondrial respiration, hormone biosynthesis, production and scavenging of reactive oxygen species, and osmo-protection (Haensch, 
Mendel, 2009). Also, it is a component of many important enzymes associated with some important issues such as energy transfer, nitrogen reduction and pathogen defense. Moreover, zinc is a necessary component of various enzyme systems for energy production, protein synthesis, it maintains the structural integrity of bio-membranes and growth regulation (Haensch, Mendel, 2009). The uptake of zinc is affected strongly by high levels of available phosphorus and iron in soils (Ghasemi-Fasaei, Ronaghi, 2008). It seems that this type of antagonistic effect can be diminished by foliar application.

In recent years, some researchers tried to examine the potential of nanotechnology to improve efficiency of micronutrients uptake that result in the development of efficient new nanofertilizer delivery systems for field application (Naderi, Danesh-Shahraki, 2013; Rameshaiah, Jpallavi, 2015). Nano-formulated fertilizers can release nutrients more slowly in cooperation with other fertilizers which may lead to improvement of nutrient use efficiency. Application of nanofertilizers may improve solubility and dispersion of insoluble nutrients in soil, reduce nutrient immobilization and increase bio-availability (Naderi, DaneshShahraki, 2013). Nanofertilizers can be easily absorbed by crops and may exhibit a prolonged effective duration of nutrient supply in soil/ crop compared to the conventional fertilizers (Rameshaiah, Jpallavi, 2015).

Zhang et al. (2006) studied the effects of slow release fertilizers cemented and coated by nanomaterials. It was found that nanocomposites were safe for seed germination, emergence, and seedling growth because they provide an efficient tool for regulated and timely delivery of nutrients to crops. The application of zinc nanofertilizer on pearl millet improved some properties such as shoot length, root length, root area, chlorophyll content, total soluble leaf protein, and plant dry biomass (Tarafdar et al., 2014). In this study, the grain yield at crop maturity was improved by $37.7 \%$ due to application of zinc nanofertilizer.
Several investigations indicate that exogenous application of some nanoparticles can improve plant growth (Mandeh et al., 2012; Song et al., 2013). Titanium dioxide nanoparticles (nano- $\mathrm{TiO}_{2}$ ) are promising as an efficient nutrient source for crops to improve biomass production due to enhanced nitrogen assimilation, photo-reduction activities of photosystem II and electron transport chain, protecting the chloroplast membrane structure from reactive oxygen species (Morteza et al., 2013). Also, nano- $\mathrm{TiO}_{2}$ can improve utilization of native nutrients by promoting microbial activities (Raliya et al., 2015).

In Iran, zinc and iron deficiencies are nutritional disorders in most of the crops grown in dry land conditions, and these nutrients are meaningfully involved in grain yield production. The deficiency of zinc and iron may occur frequently in semiarid regions, and so the present study was performed to improve understanding about the foliar application of nano-chelated iron and zinc fertilizers as well as nano- $\mathrm{TiO}_{2}$ on yield and other important traits of barley.

\section{MATERIALS AND METHODS}

The treatments included factor micronutrient fertilizers (iron nano-chelate, zinc nano-chelate, and control) and foliar application of nano-titanium at two levels (without application and $2000 \mathrm{ppm}$ ). Micronutrient nanofertilizers were applied three times during initiation of the tillering stage, booting, and milky stage. $\mathrm{Na}$ no-titanium solution was sprayed on the plant leaves at the end of vegetative growth (double ridge stage) and during the inflorescence emergence. Treatments were applied according to randomization complete blocks design in factorial layout with three replicates. Nanotitanium $\left(\mathrm{nTiO}_{2}\right)$ was prepared from Pishgaman Nano, Iran, and nano-chelate fertilizers were obtained from Sepeher Parmis Company, Iran, which contained zinc oxide or iron oxide nanoparticles. Synthesized nanoparticles were characterized morphologically by transmission electron microscopy (Fig. 1). The yield and other 


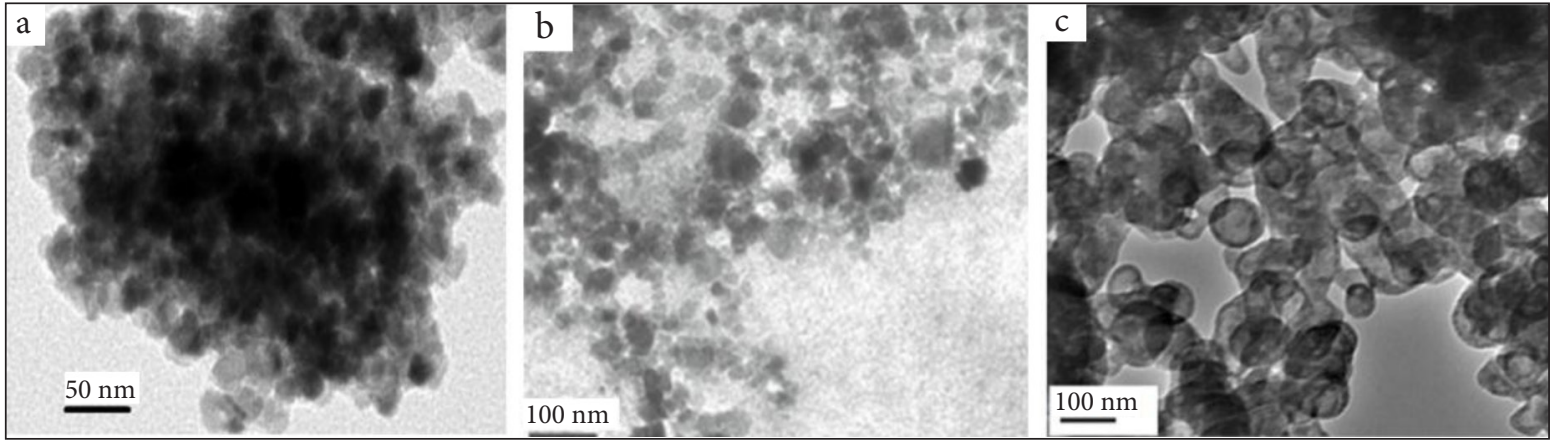

Fig. 1. Transmission electron microscopy (TEM) micrograph of synthesized $\mathrm{TiO}_{2}$ nanoparticles (a), nano zinc oxide (b) and iron oxide nanoparticles (c) nanoparticles

traits, including plant height, number of fertile tillers, straw weight, panicle length, number of grains/panicle, 1000 grain weight and grain yield were measured.

The biplot analysis was done according to Model 2 (Transform $=0$ ) within-trait standard deviation standardized (Scale $=1$ ), and traitcentred (Centering=2). The polygon views were based on genotype-focused singular value partitioning $(\mathrm{SVP}=2)$, while the vector views were based on the trait-focused singular value partitioning and is, therefore, appropriate for visualizing the relationships among traits. The genotype by trait (GT) biplot model equation (Yan, Rajcan, 2002) for genotype by trait interaction biplot analysis is presented as follows:

$$
\frac{\alpha_{i j}-\beta_{j}}{\sigma_{j}}=\sum_{n=1}^{2} \lambda_{n} \xi_{i n} \eta_{j n}+\varepsilon_{i j}=\sum_{n=1}^{2} \xi_{i n}^{*} \eta_{j n}^{*}+\varepsilon_{i j}
$$

where $\alpha_{i j}$ is the mean value of landrace $i$ for trait $j, \beta_{j}$ is the mean value of all landraces in trait $j, \sigma_{i j}$ is the standard deviation of trait $j$ among the landrace means, $\lambda_{n}$ is the singular value for principal component $n$ (PCn), $\zeta_{\text {in }}$ and $\eta_{j n}$ are scores for landrace $i$ and trait $j$ on PCn, respectively, and $\varepsilon_{i j}$ is the residual associated with landrace $i$ in trait $j$. To achieve symmetric scaling between the landrace scores and the trait scores, the singular value $\lambda_{n}$ has to be absorbed by the singular vector for landraces $\zeta_{\text {in }}$ and that for traits $\eta_{j n}$. That is, $\zeta_{\text {in }}^{*}=\zeta_{i n} \lambda^{0.5}{ }_{n}$ and $\eta_{j n}^{*}=\eta_{j n} \lambda_{n}^{0.5}$. Because of $n=2$, only PC1 and PC2 are retained in the model, and such a model tends to be the best for extracting pattern and rejecting noise from the data.

\section{RESULTS AND DISCUSSION}

The GT biplot for wheat dataset, based on Model 2, explained $83 \%$ of the total variation of the standardized data. This relatively high percentage reflects the complexity of the relationships among the measured traits of safflower. The first two principal components (PC1 and PC2) explained 69 and 14\%, respectively. In the GT biplot, a vector is drawn from the biplot origin to each marker of the genotype to facilitate visualization of the relationships between and among the traits as well as treatment combinations. Based on Sabaghnia and Janmohammadi (2014b), the basic structure among the traits should be captured by the biplots for better interpretations. The polygon view of the GT biplot aids identifies treatment combinations with the highest values for one or more traits. For this target, the treatment combinations that are connected with straight lines so that a polygon is formed with all other traits contained within the polygon.

The biplot of Fig. 2 presents data of six treatment combinations in 15 different traits and this following information can be grasped: The vertex treatment combinations in this investigation are treatment combinations $\mathrm{F} 1 \mathrm{n} 1, \mathrm{~F} 1 \mathrm{n} 2$, F2n2, F3n1, and F3n2. These treatment combinations are the best or the poorest treatment combinations in some or all of the traits since 


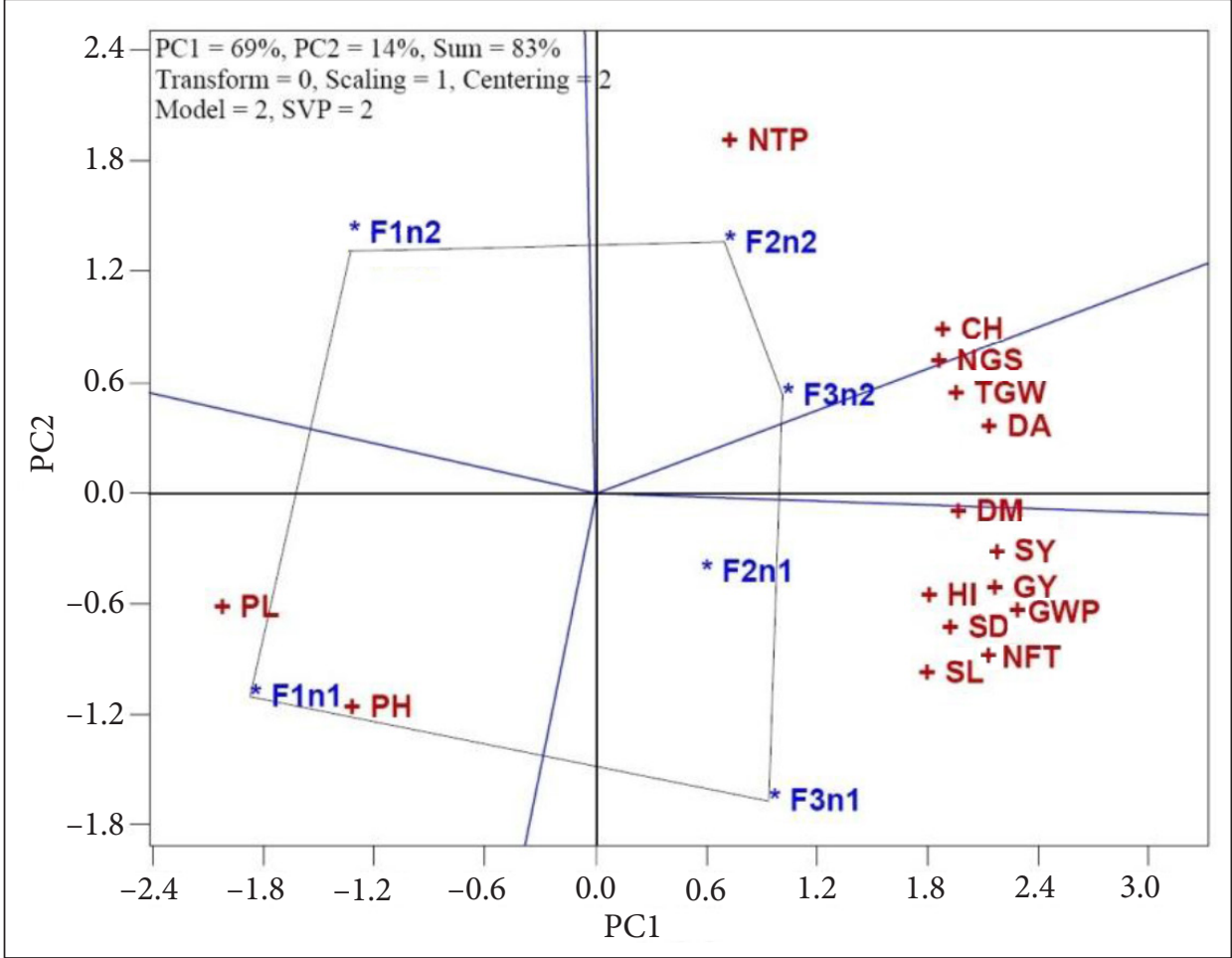

Fig. 2. Polygon view treatment combination (nanofertilizer $\times$ nano- $\mathrm{TiO}_{2}$ ) by trait biplot showing which treatment combination had the highest values for which traits

they had the longest distance from the origin of biplot. Therefore, it seems that F3n1 treatment combination had the highest values for all of the DM, SY, HI, SY, SD, SL, NFT, and GWP traits. The treatment combinations F3n1 and the other treatment combinations (F2n1) of this sector had good amounts for the abovementioned traits. The vertex treatment combinations F3n2 were good for DA and TGW traits, while the vertex treatment combinations F1n1 were good for PL and PH traits. The vertex treatment combinations F2n2 were good for $\mathrm{CH}, \mathrm{NGS}$, and NTP traits. The other vertex treatment combination (F1n2) and related sectors were not good performance for the measured traits (Fig. 2).

Provided that the biplot model described a sufficient amount of the total variation (in this case, $83 \%$ ), the correlation coefficient between any two traits is approximated by the cosine of the angle between their vectors (Yan, Rajcan, 2002). The correlation coefficients among the traits indicate that the biplot currently indicates relationship among the traits that had a relatively large loading on both PC1 and PC2. Therefore, the most prominent relations by this Fig. 3 are: a strong positive association between $\mathrm{DM}$ and SY; among $\mathrm{CH}$, NGS and TGW; and among GY, HI, GWP, SD, NFT and SL; as indicated by the small obtuse angles between their vectors $(r=\cos 0=+1)$. There was a near zero correlation between NTP with DM and SY as indicated by the near perpendicular vectors $(r=\cos 90=0)$. There was a negative correlation between $\mathrm{PH}$ with $\mathrm{CH}$, NGS and TGW traits; and between PL and DA traits (Fig. 3) as indicated by the near an angle of approximately 180 degrees $(r=\cos 180=-1)$. Most discrepancies of the biplot predictions and original data (Table) were expected because the biplot accounted for $<100 \%$ of the total variation ( $83 \%$ ).

In the context of GT biplot analysis, an ideal tester of a trait has been defined as the tester that combines several good treatment combinations in its genetic composition (Sabaghnia, Janmohammadi, 2014a). According to Fig. 4, the ideal trait is strongly related to as SY and DM traits following to TGW, DA, GY, HI, GWP, 


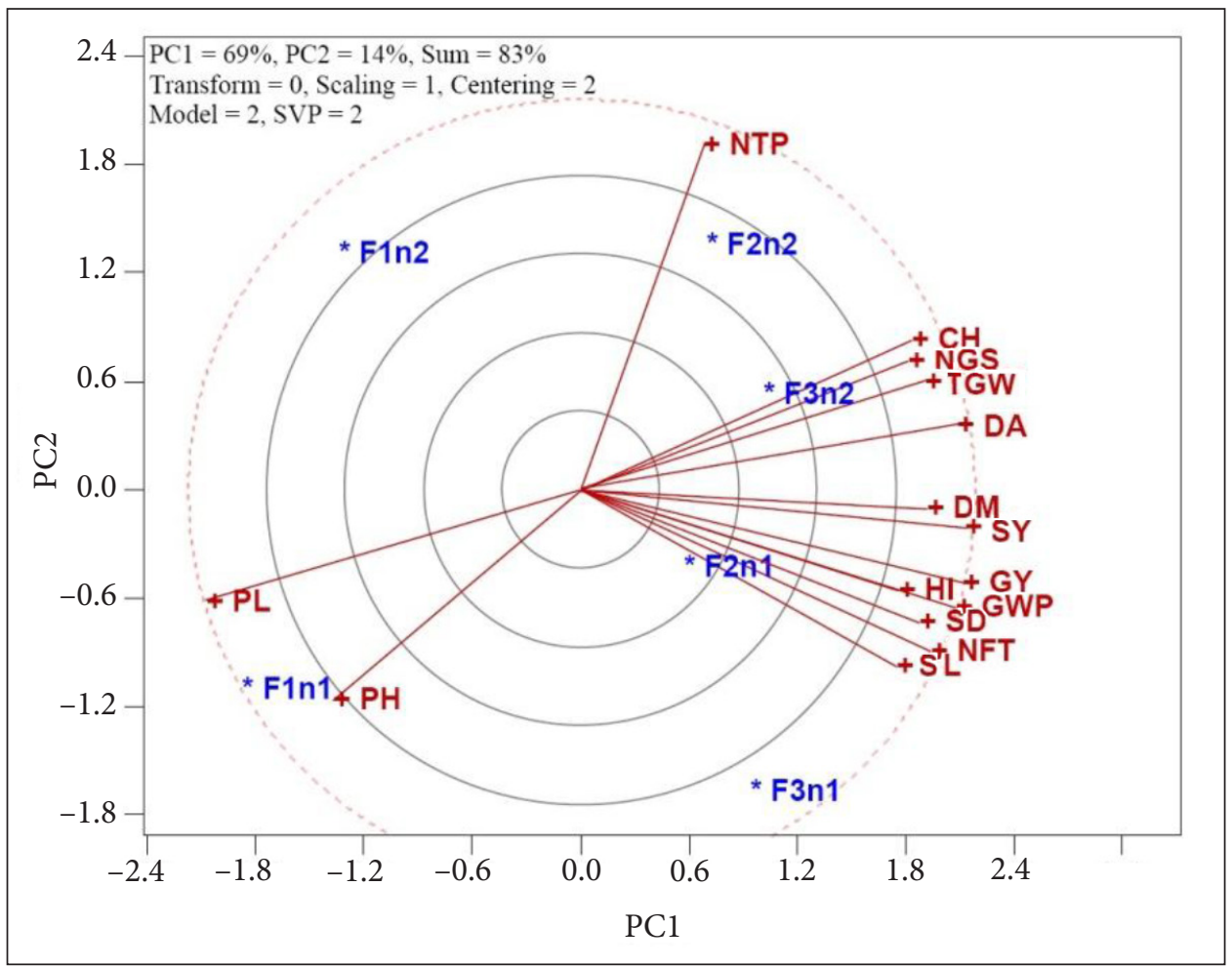

Fig. 3. Vector view treatment combination (nanofertilizer $\times$ nano- $\mathrm{TiO}_{2}$ ) by trait biplot, showing the interrelationship among all measured traits

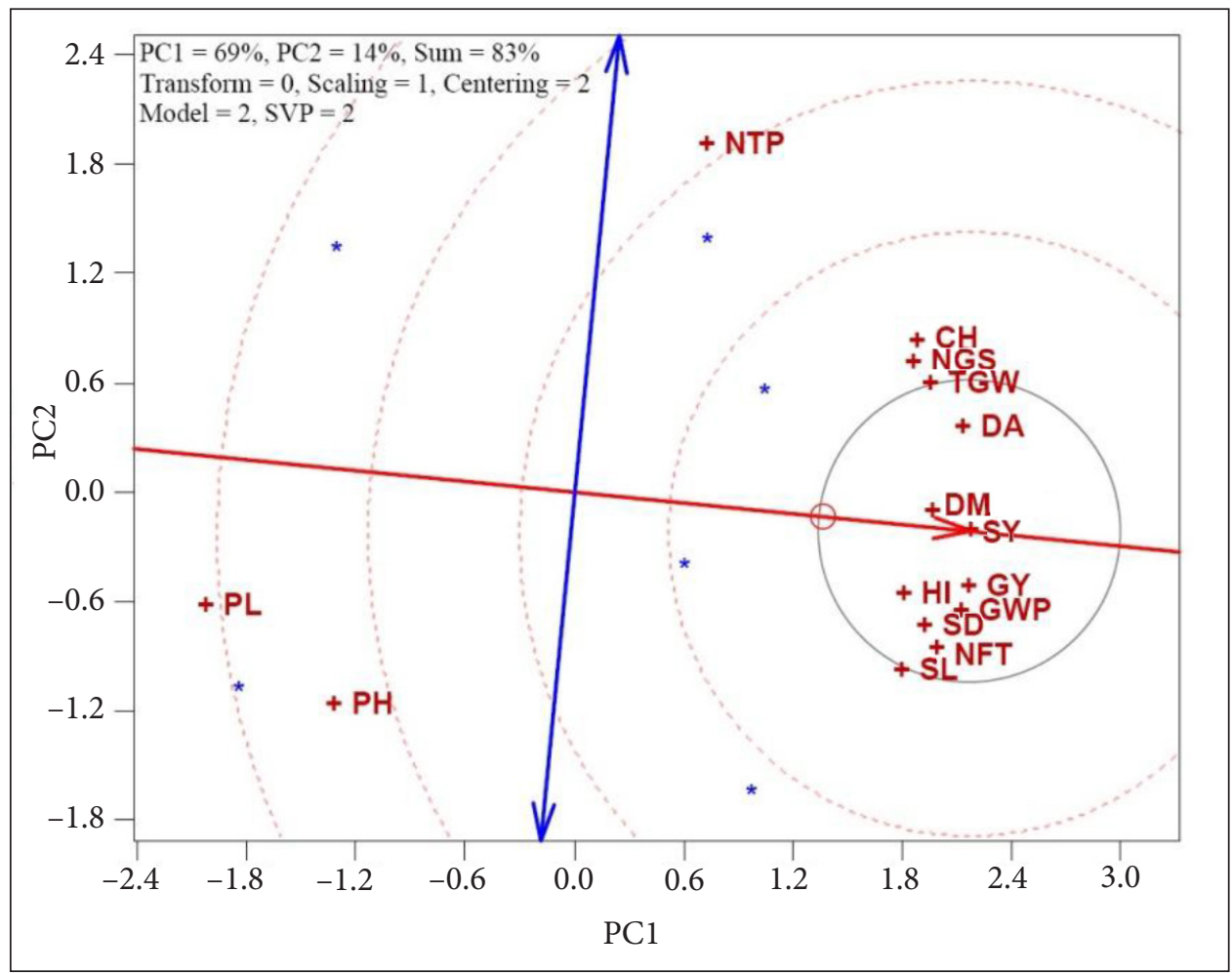

Fig. 4. Ideal tester view of treatment combination (nanofertilizer $\times$ nano- $\mathrm{TiO}_{2}$ ) by trait biplot, showing the relationships of the measured traits 
Table. Correlation coefficients among some morphological traits of barley

\begin{tabular}{|c|c|c|c|c|c|c|c|c|c|c|c|c|c|c|}
\hline & PH & SD & NTP & NFT & GWP & NGS & PL & SL & TGW & DA & DM & $\mathrm{CH}$ & GY & SY \\
\hline SD & -0.41 & & & & & & & & & & & & & \\
\hline NTP & -0.01 & -0.11 & & & & & & & & & & & & \\
\hline NFT & -0.43 & 0.46 & 0.60 & & & & & & & & & & & \\
\hline GWP & $\begin{array}{l}-0.09 \\
\end{array}$ & 0.70 & 0.52 & 0.61 & & & & & & & & & & \\
\hline NGS & -0.12 & 0.38 & 0.73 & 0.79 & 0.85 & & & & & & & & & \\
\hline PL & 0.21 & -0.71 & -0.58 & -0.74 & -0.98 & -0.87 & & & & & & & & \\
\hline SL & 0.27 & 0.68 & 0.03 & 0.07 & 0.79 & 0.41 & -0.68 & & & & & & & \\
\hline TGW & -0.29 & 0.74 & 0.57 & 0.76 & 0.90 & 0.75 & -0.96 & 0.59 & & & & & & \\
\hline DA & -0.25 & 0.22 & 0.77 & 0.77 & 0.71 & 0.96 & -0.75 & 0.19 & 0.62 & & & & & \\
\hline $\mathrm{DM}$ & -0.26 & 0.70 & 0.09 & 0.47 & 0.77 & 0.72 & -0.73 & 0.63 & 0.55 & 0.65 & & & & \\
\hline $\mathrm{CH}$ & -0.40 & 0.46 & 0.68 & 0.77 & 0.83 & 0.94 & -0.87 & 0.36 & 0.76 & 0.95 & 0.76 & & & \\
\hline GY & -0.11 & 0.62 & 0.63 & 0.73 & 0.98 & 0.93 & -0.99 & 0.67 & 0.91 & 0.81 & 0.75 & 0.89 & & \\
\hline SY & -0.06 & 0.34 & 0.80 & 0.73 & 0.87 & 0.98 & -0.89 & 0.46 & 0.77 & 0.94 & 0.66 & 0.93 & 0.94 & \\
\hline HI & -0.20 & 0.94 & 0.13 & 0.52 & 0.85 & 0.54 & -0.86 & 0.81 & 0.87 & 0.34 & 0.68 & 0.55 & 0.89 & 0.53 \\
\hline
\end{tabular}

Critical values of correlation $P<0.05$ and $P<0.01$ are 0.79 and 0.90 , respectively. $\mathrm{PH}=$ plant height, $\mathrm{SD}=$ stem diameter $(\mathrm{mm}), \mathrm{NTP}=$ number of tillers per plants, NFT = number of fertile tillers, GWP = grain weight per plant, NGS = number of grain per spike, $\mathrm{PL}=$ peduncle length, $\mathrm{SL}=$ spike length, $\mathrm{TGW}=1000$ grain weight, $\mathrm{DA}=$ days to anthesis, $\mathrm{DM}=$ days to maturity, $\mathrm{CHL}=$ chlorophyll (SPAD unit), GY = grain yield, $\mathrm{SY}=$ straw yield, $\mathrm{HI}=$ harvest index.

SD, NFT, and SL traits. It is interesting that the grain yield, straw yield, and harvest index exist in these traits. Therefore, these important traits must be regarded in the barley evaluation programs. On the other hand, the studied treatment combinations had good performances for obtain economic and commercial traits (GY, $\mathrm{HI}$, and SY).

Due to a large importance of F3n2 treatment combination (iron nano-chelate, zinc nano-chelate), this treatment combination was compared in the studied treatment combinations (Fig. 5). The most related treatment combinations in this context are $\mathrm{F} 2 \mathrm{n} 1$ and $\mathrm{F} 2 \mathrm{n} 2$ treatment combinations. The importance of these treatment combinations, especially nano-titanium dioxide $\left(\mathrm{TiO}_{2}\right)$, application in obtaining good performance of barley is demonstrated, which is reported in other investigations (Moaveni et al., 2011; Shaw et al., 2014). Previous investigations have demonstrated significant differences among treatment combinations for yield and their related traits by application of different nanoparticles (Gao et al., 2013; Rezaei et al., 2015).
Our results showed that foliar application of zinc nano-chelate with nano-titanium dioxide $\left(\mathrm{TiO}_{2}\right)$ could increase most of the important traits of barley such as grain yield, straw yield, thousand grain weight, and harvest index. Higher GTW indicates increased individual grain sink strength which can be depicted as the output of sink activity and sink size (Yang et al., 2003). Nano-titanium dioxide $\left(\mathrm{TiO}_{2}\right)$ can enhance photosynthesis by promoting cyclic and linear photophosphorylation (Gao et al., 2013) and it can result in enhancement of carbohydrate production in leaves, and its positive effect on most traits of barley is in good agreement with the findings of Rezaei et al. (2015). There are some compensating effects between grain number per spike and grain weight in the current study because application of nanofertilizers increased both traits and their effects appeared in higher grain yield.

According to Morteza et al. (2013), foliar utilization of nano-Tio ${ }_{2}$ can improve plant growth and grain yield by facilitating the manufacture of pigments and transformation of light energy to active electron and chemical 


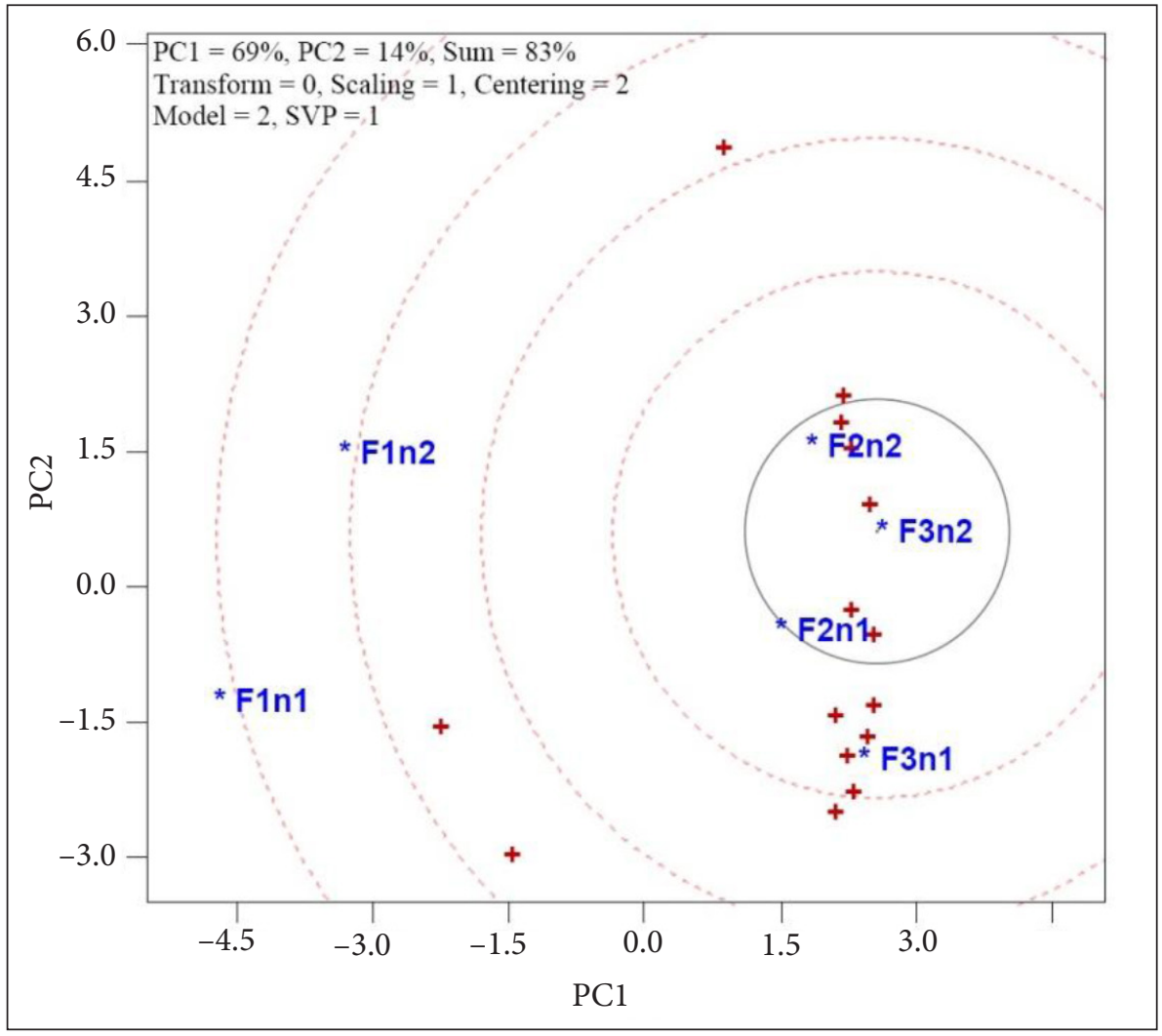

Fig. 5. Tester comparison view of treatment combination by trait biplot, showing the relationships of traits with $\mathrm{F} 3 \mathrm{n} 2$ treatment combination (zinc nano-chelate with 2000 ppm nano- $\mathrm{TiO}_{2}$ )

activity and increases photosynthetic efficiency. It has been recognized that plants under optimum conditions tend to increase the duration of their development as much as possible which can result in improved leaf photosynthesis, light-use potential, and higher yield (Cui et al., 2015). This study verified the previous reports that application of nanofertilizers (iron nano-chelate and zinc nano-chelate) and nano- $\mathrm{Tio}_{2}$ considerably influenced the straw and grain yield. The results of our study suggested that yield and yield components of barley can be positively affected by nano- $\mathrm{TiO}_{2}$ and nanofertilizers. The results of other studies demonstrated $\mathrm{TiO}_{2}$ nanoparticle as an efficient photocatalyst by improving photosynthetic complexes (Klingenfuss, 2014; Raliya et al., 2015), while evidence from this study suggested that this nanoparticle along with nanofer- tilizers (treatment combination F3n2 or zinc nano-chelate with 2000 ppm nano- $\mathrm{TiO}_{2}$ ) can effectively influence characteristics of barley.

\section{CONCLUSIONS}

Nano-micronutrient fertilizers (iron nanochelate and zinc nano-chelate) stand out as one of the most useful materials due to their high efficiency, functionalities, convenient and easy applications. Also, it can be concluded that $\mathrm{TiO}_{2}$ nanoparticles could increase yield and yield components of barley. Our findings suggest that the foliar application of nanoparticles resulted in sustainable and high crop production. Among six treatment combinations, F3n2 (zinc nano-chelate with 2000 ppm nano$\mathrm{TiO}_{2}$ ) indicated the best performance for most of the measured traits of barley. 


\section{ACKNOWLEDGEMENTS}

We wish to thank Dr. Wei-Kai Yan (Eastern Cereal Oilseed Research Center of Agriculture and Agri-Food Canada) for making available a time-limited version of GGEbiplot as "testBiplotxlsx".

Received 22 March 2015 Accepted 30 June 2016

\section{References}

1. Cui Y, Tian Z, Zhang X, Muhammad A, Han H, Jiang D, Cao W, Dai T. Effect of water deficit during vegetative growth periods on post-anthesis photosynthetic capacity and grain yield in winter wheat (Triticum aestivum L.). Acta Physiologiae Plantarum. 2015; 37: 196-217.

2. Gao J, Xu G, Qian H, Liu P, Zhao P, Hu Y. Effects of nano- $\mathrm{TiO}_{2}$ on photosynthetic characteristics of Ulmus elongata seedlings. Environmental Pollution. 2013; 176: 63-70.

3. Ghasemi-Fasaei R, Ronaghi A. Interaction of iron with copper, zinc, and manganese in wheat as affected by iron and manganese in a calcareous soil. J Plant Nutr. 2008; 31: 839-48.

4. Haensch R, Mendel RR. Physiological functions of mineral micronutrients $(\mathrm{Cu}, \mathrm{Zn}, \mathrm{Mn}$, $\mathrm{Fe}, \mathrm{Ni}, \mathrm{Mo}, \mathrm{B}, \mathrm{Cl})$. Current Opinion in Plant Biology. 2009; 12: 259-66.

5. Klingenfuss $\mathrm{F}$. Testing of $\mathrm{Tio}_{2}$ nanoparticles on wheat and microorganisms in a soil microcosm [thesis for master of science in ecotoxicology]. University of Gothenburg; 2014. 62 p.

6. Mandeh $M$, Omidi $M$, Rahaie $M$. In vitro influences of $\mathrm{TiO}_{2}$ nanoparticles on barley (Hordeum vulgare L.) tissue culture. Biological Trace Element Research. 2012; 150: 376-80.

7. Morteza E, Moaveni P, Farahani HA, Kiyani M. Study of photosynthetic pigments changes of maize (Zea mays L.) under nano $\mathrm{TiO}_{2}$ spraying at various growth stages. SpringerPlus. 2013; 2: $1-5$.
8. Naderi MR, Danesh-Shahraki A. Nanofertilizers and their roles in sustainable agriculture. Int J Agri Crop Sci. 2013; 5: 2229-32.

9. Raliya R, Biswas P, Tarafdar JC. $\mathrm{TiO}_{2}$ nanoparticle biosynthesis and its physiological effect on mung bean (Vigna radiate L.). Biotechnology Reports. 2015; 5: 22-6.

10. Rameshaiah GN, Jpallavi S. Nano fertilizers and nano sensors-an attempt for developing smart agriculture. Int J Eng Res Gen Sci. 2015; 3: 314-20.

11. Rezaei F, Moaveni P, Mozafari H. Effect of different concentrations and time of nano $\mathrm{Tio}_{2}$ spraying on quantitative and qualitative yield of soybean (Glycine max L.) at Shahr-e-Qods, Iran. Biological Forum. 2015; 7: 957-64.

12. Sabaghnia N, Janmohammadi M. Graphic analysis of nano-silicon by salinity stress interaction on germination properties of lentil using the biplot method. Agriculture and Forestry. 2014a; 60: 29-40.

13. Sabaghnia N, Janmohammadi M. Interrelationships among some morphological traits of wheat (Triticum aestivum L.) cultivars using biplot. Botanica Lithuanica. 2014b; 20: 19-26.

14. Song U, Shin M, Lee G, Roh J, Kim Y, Lee EJ. Functional analysis of $\mathrm{TiO}_{2}$ nanoparticle toxicity in three plant species. Biological Trace Element Research. 2013; 155: 93-103.

15. Yan W, Rajcan I. Biplot evaluation of test sites and trait relations of soybean in Ontario. Crop Science. 2002; 42: 11-20.

16. Tarafdar JC, Raliya R, Mahawar H, Rathore I. Development of zinc nanofertilizer to enhance crop production in pearl millet (Pennisetum americanum). Agricultural Research. 2014; 3: 257-262.

17. Yang J, Zhang J, Wang Z, Zhu Q. Hormones in the grains in relation to sink strength and postanthesis development of spikelets in rice. Plant Growth Regulation. 2003; 41: 185-195.

18. Zhang F, Wang R, Xiao Q, Wang Y, Zhang J. Effects of slow/controlled-release fertilizer cemented and coated by nano-materials on biology. II. Effects of slow/controlled-release fertilizer cemented and coated by nano-materials on plants. Nanoscience. 2006; 11: 18-26. 
19. Moaveni P, Talebi AH, Farahani A, Maroufi K. Study of nano particles $\mathrm{TiO}_{2}$ spraying on some yield components in barley (Hordem vulgare L.). International Conference on Environmental and Agriculture Engineering; 2011. p. 115-119.

20. Shaw AK, Ghosh S, Kalaji HM, Bosa K, Brestic M, Zivcak M, Hossain Z. Nano-CuO stress induced modulation of antioxidative defense and photosynthetic performance of Syrian barley (Hordeum vulgare L.). Environ Exp Bot. 2014; 102: 37-47.
Mohsen Janmohammadi, Naser Sabaghnia, Shahryar Dashti, Mojtaba Nouraein

\section{KAI KURIŲ MIEŽIŲ SAVYBIŲ TYRIMAS NAUDOJANT NANO MIKROELEMENTŲ TRĄŠAS IR NANO TITANO DIOKSIDĄ ANT LAPŲ}

\section{Santrauka}

Nano trąšos yra nauji produktai, kurių sudètyje yra lengvai pasisavinamų maistinių medžiagų, todèl jos dažniausiai naudojamos dèl jų efektyvumo. Siekiant ištirti nano mikroelementų trąšų (geležies ir cinko) kaip $\mathrm{F}$ veiksnio ir nano titano dioksido $\left(\right.$ nano $\mathrm{TiO}_{2}$ ) tirpalo kaip $n$ veiksnio poveiki derliaus našumui ir kai kurioms miežių morfologinèms savybẻms, lauko eksperimento metu augalai buvo apdorojami cinko oksido (nano $\mathrm{ZnO}$ ) ir geležies oksido (nano $\mathrm{Fe}_{2} \mathrm{O}_{3}$ ) suspensijomis per tris fenologinius etapus. Tyrimo rezultatai rodo, kad titano dioksido nano dalelès ir nano mikroelementų trąšos (geležies nano chelatas ir cinko nano chelatas) galètu padidinti miežių derlių ir jo komponentus. Gautais duomenimis, nano dalelès ant lapų lèmè tvarią ir produktyvią augalininkystę, o tarp šešių apdorojimo kombinacijų F3n2 (cinko nano chelatas ir 2000 ppm nano $\mathrm{TiO}_{2}$ ) turejo didžiausią poveikị daugumai išmatuotų miežių savybių.

Raktažodžiai: nano trą̌̌os, geležies nano chelatas, $\mathrm{TiO}_{2}$, cinko nano chelatas 